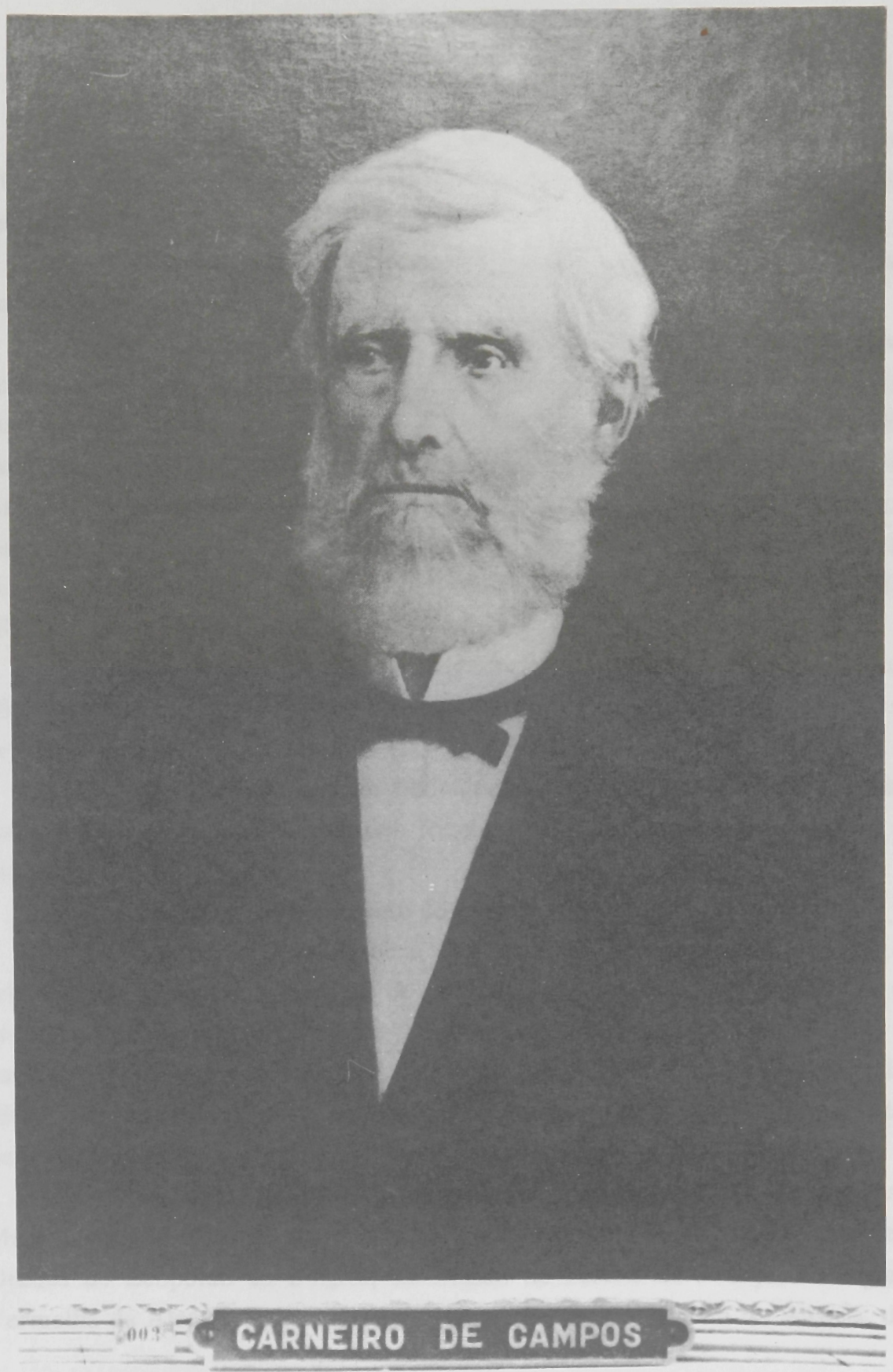





\section{Conselheiro Dr. CARLOS CARNEIRO DE CAMPOS \\ (Visconde de Caravellas)}

(1833-1835)

Natural da Bahia, nasceu Carlos Carneiro de Campos, o terceiro Visconde de Caravellas, em $1^{\circ}$ de novembro de 1805 . Serviu como cadete no batalhão de D. Pedro I.

Freqüentou a Escola Militar. Cursou a Universidade de Coimbra, onde se graduou em direito.

Nomeado, por decreto de 9 de fevereiro de 1829, lente catedrático de economia política, primeira cadeira do quinto ano, tomou posse em 13 de maio de 1829; mas o aviso de 10 de fevereiro do mesmo ano, do ministro do Império, José Clemente Pereira, determinou que fosse servindo como substituto interino, enquanto se não verificasse o exercício da sua cadeira. Serviu, também, interinamente, de secretário, de fevereiro de 1832 a 19 de agosto de 1833, data em que passou a diretor interino, exercendo este cargo até 24 de outubro de 1833, em que foi nomeado inspetor do Tesouro.

Por decreto de 24 de dezembro de 1833, foi nomeado diretor efetivo, tomando posse a 27 do mesmo mês. Exerceu o cargo até 5 de novembro de 1835 .

Fundou a Sociedade Filomática, de cuja revista foi diretor, em companhia de Francisco Bernardino Ribeiro, José Ignacio Silveira da Motta e outros.

Foi jubilado por decreto de 29 de janeiro de 1858 .

Deputado à Assembléia Provincial da Bahia, deputado geral e senador por São Paulo, desde 19 de abril de 1853, presidiu, por três vezes, a provincia de Minas Gerais. Foi vice-presidente de São Paulo, em 1852. Ocupou a pasta dos Estrangeiros nos gabinetes de 24 de maio de 1862, de 31 de agosto de 1864, de 7 de março de 1871, e a pasta da Fazenda no gabinete de 31 de agosto de 1864.

Recebeu os títulos de Conselheiro de Estado, Viador de Sua Majestade a Imperatriz, Comendador da Ordem de Cristo, Grão-Cruz das Ordens de Leopoldo da Bélgica, da Legião de Honra da França, da Águia Vermelha da Alemanha, da Coroa da Itália, da Coroa de Ferro da Áustria, da 
Ernestina, de Saxe Coburgo e Gotha, o que demonstra os altos serviços prestados ao Brasil e os seus grandes méritos.

Faleceu em 19 de fevereiro de 1878. 